\title{
Production and Properties of Alkaline Lipase from Alcaligenes sp. Strain No. $679^{\dagger}$
}

\author{
Yoshitaka KoKusho, Haruo MaCHIDA \\ and Shinjiro IwASAKI \\ Tokyo Research Laboratory, Meito Sangyo Co., Ltd., \\ Hachioji, Tokyo 192, Japan \\ Received July 31, 1981
}

\begin{abstract}
For the production of extracellular lipase by Alcaligenes species $\mathrm{No} .679, \mathrm{NaNO}_{3}$, polyoxyethylene alkyl ether, $\mathrm{Fe}^{++}$, sodium citrate and fructose were found to be effective. The enzyme was prepared by acetone precipitation from the filtrate of the culture broth of this strain. The enzyme was most active at $\mathrm{pH} 9.0$ and $50^{\circ} \mathrm{C}$, while $35 \%$ of its activity was lost on heat treatment at $60^{\circ} \mathrm{C}$ for $10 \mathrm{~min}$. Sodium salts of bile acids stimulated the enzyme activity. This lipase could hydrolyse natural fats and oils as well as olive oil. During the hydrolysis of olive oil, monoglyceride was found to accumulate up to $70 \mathrm{~mol}$ percent. This lipase possesses special properties similar to those of pancreatic lipase as shown in the comparative experiments.
\end{abstract}

With the recent increase in research on microbial lipases, many lipases of various characteristics have been found. For instance, Watanabe ${ }^{1)}$ reported on alkaline lipase, and $\mathrm{Kosugi}^{2)}$ and Arima $^{3)}$ reported on thermostable lipase. Sugiura ${ }^{4)}$ and Tomoda ${ }^{5)}$ found that the lipases from Mucor and Phycomyces were stimulated by bile salts.

As reported in the previous paper, ${ }^{6)}$ we found two Alcaligenes strains which produced lipases similar to pancreatic lipase. This paper deals with some cultural conditions for lipase production by Alcaligenes sp. No. 679 and the enzymatic properties of the acetone precipitated fraction of the culture filtrate compared with those of pancreatic lipase.

\section{MATERIALS AND METHODS}

Microorganism. The microorganism used in this study was Alcaligenes sp. No. 679.

Materials. Pancreatic lipase preparation (Wilzyme-400) was purchased from Wilson Laboratories. Olive oil and other natural fats were purchased from Yuro Yakuhin
Co., Ltd. SC, SDC, and SGC were obtained from Sigma Chemical Co. and STC was from Difco Laboratories. Other chemicals were obtained from commercial sources.

Cultivation of microorganism. Fifty $\mathrm{ml}$ of culture medium in a $500 \mathrm{ml}$ shaking flask was inoculated with a loopful of the microorganism from a slant culture and incubated at $25^{\circ} \mathrm{C}$ for 2 days with shaking. The basal culture medium consisted of 3\% kinako (roasted soybean meal), $1 \%$ wheat starch, $1 \% \mathrm{NaNO}_{3}$ and $0.2 \% \mathrm{~K}_{2} \mathrm{HPO}_{4}$.

Preparation of the enzyme sample. The microorganism was cultured in a medium which was composed of $3 \%$ kinako, $0.75 \% \mathrm{NaNO}_{3}, 0.028 \% \mathrm{FeSO}_{4} \cdot 7 \mathrm{H}_{2} \mathrm{O}, 0.6 \%$ sodium citrate, $1.25 \%$ fructose, $0.5 \%$ polyoxyethylene stearyl ether and $0.4 \%$ silicon KM-72 (antifoamer), adjusted to $\mathrm{pH}$ 7.2. The culture broth was centrifuged to remove cells and other solids. Acetone was added to the supernatant fluid to $80 \%(\mathrm{v} / \mathrm{v})$. The enzyme precipitate was collected by filtration, washed twice with acetone and dried in vacuo. This powder was used in this study. This preparation was assayed and found to contain $1.2 \times 10^{5}$ units/g according to assay method II described later.

Determination of lipase activity. The assay of lipase activity was carried out according to the following two methods. Assay method I was as described in the previous paper. ${ }^{6)}$ The activity in the culture fluid was measured according to this method. Assay method II was described

+ Studies on the Alkaline Lipase. Part II. For Part I, see ref. 6.

Abbreviations: SC, sodium cholate; SDC, sodium deoxycholate; SGC, sodium glycocholate; STC, sodium taurocholate; lipase-Panc, pancreatic lipase preparation; lipase-PL, lipase preparation from Alcaligenes sp. No. 679; TLC, thin layer chromatography; HLB, hydrophilic-lipophilic balance; AV, acid value; SV, saponification value. 
in the report of the Federation Internationale Pharmaceutique. ${ }^{7)}$ One $\mathrm{ml}$ of enzyme solution was mixed with $10 \mathrm{ml}$ of olive oil emulsion, $17 \mathrm{ml}$ of $5 \mathrm{~mm}$ Trisaminomethane- $\mathrm{NaCl}$ buffer and $2 \mathrm{ml}$ of $8 \%$ STC solution and kept at $37^{\circ} \mathrm{C}$. The olive oil emulsion was prepared according to the method described in the previous paper. ${ }^{6)}$ Fatty acid liberated by the lipase reaction was automatically titrated in a pH-stat (TOA Electric Co., HS-2A), to keep the reaction mixture constantly at $\mathrm{pH} 9.0$. One unit is defined as the enzyme amount which liberates one microequivalent of fatty acid per minute under the assay conditions. The enzyme properties of the lipase were studied according to this method. One lipase unit for method I is equivalent to about 2.7 lipase units for method II.

Hydrolysis of fats and oils. The reaction mixture containing $2 \mathrm{~g}$ of fats or oils, $4 \mathrm{ml}$ of artificial intestinal juice, ${ }^{*}$ $1 \mathrm{ml}$ of $8 \%$ STC solution and $1 \mathrm{ml}$ of lipase solution containing 200 units, was shaken at 60 oscillation per min for $60 \mathrm{~min}$ at $37^{\circ} \mathrm{C}$. Free fatty acid in the reaction mixture was determined according to assay method I.

Hydrolysis of olive oil. The reaction mixture composed of $50 \mathrm{~g}$ of olive oil, $1.2 \mathrm{~g}$ of STC, $98 \mathrm{ml}$ of $1 \mathrm{M}$ glycine$\mathrm{NaOH}$ buffer ( $\mathrm{pH} 9.1$ ), and $1 \mathrm{~g}$ of lipase preparation was kept at $37^{\circ} \mathrm{C}$ in a $300 \mathrm{ml}$ flask with stirring. During hydrolysis, the $\mathrm{pH}$ of the mixture was adjusted to $8 \sim 9$ with $10 \mathrm{~N} \mathrm{NaOH}$ solution and an aliquot was taken periodically. The oily fraction of the sample was extracted on the acidic side with ethyl ether. The upper layer was washed with saturated $\mathrm{NaCl}$ solution, dehydrated with anhydrous $\mathrm{Na}_{2} \mathrm{SO}_{4}$, and then ethyl ether was distilled off.

Analysis of hydrolyzate. Determination of AV and SV of the oily fraction were carried out according to the "Standard of the Analytical Method" edited by The Japan Oil Chemical Institute. The rate of hydrolysis was calculated on the basis of AV/SV. Glycerol in the water layer was measured according to the method of Hanahan and Olley. ${ }^{8)}$ Mono-, di- and triglycerides in the oily fraction were separated by TLC. The solvent system was petroleum ether-ethyl ether-acetic acid $(80: 30: 1)$ and the fractions were visualized with iodine. Each zone of mono-, di- and triglyceride on the TLC plate was scraped off separately and saponified with $0.75 \mathrm{~N} \mathrm{KOH}$ alcohol solution. Glycerol in the saponified solution was measured as above. The molar ratio of mono-, di- and triglyceride was calculated from the quantity of glycerol.

\section{RESULTS}

\section{Cultural conditions for lipase production}

(a) Effect of nitrogen sources. The effects of organic nitrogen sources on the lipase pro- duction were investigated by adding $3 \%$ of each chemical to the basal medium instead of kinako. Corn steep liquor, yeast extract, pepton and casamino acid were less effective than kinako. Inorganic nitrogen sources were investigated in the same way as above and the results are shown in Table I. $\left(\mathrm{NH}_{4}\right)_{2} \mathrm{HPO}_{4}$ and $\left(\mathrm{NH}_{2}\right)_{2} \mathrm{CO}$ were slightly effective but the best result was obtained with $\mathrm{NaNO}_{3}$.

(b) Effect of carbon sources. Various carbohydrates were tested by putting them into basal medium instead of wheat starch. As shown in Table II, effective carbon sources were $\mathrm{Na}-$

\section{TABle I. EFFECt OF INORganic Nitrogen} Sources on the Lipase Production

One percent of each nitrogen source was added to the basal culture medium in place of $\mathrm{NaNO}_{3}$. Cultural conditions were described in MATERIALS AND METHODS.

\begin{tabular}{lcc}
\hline $\begin{array}{c}\text { Nitrogen } \\
\text { sources }\end{array}$ & $\begin{array}{c}\text { Final } \\
\text { pH }\end{array}$ & $\begin{array}{c}\text { Lipase activity in } \\
\text { supernatant fluid }(\mathrm{u} / \mathrm{ml})\end{array}$ \\
\hline $\mathrm{NH}_{4} \mathrm{H}_{2} \mathrm{PO}_{4}$ & 6.4 & 145 \\
$\left(\mathrm{NH}_{4}\right)_{2} \mathrm{HPO}_{4}$ & 6.7 & 200 \\
$\mathrm{NH}_{4} \mathrm{Cl}$ & 5.6 & 111 \\
$\left(\mathrm{NH}_{4}\right)_{2} \mathrm{SO}_{4}$ & 5.2 & 50 \\
$\mathrm{NH}_{4} \mathrm{NO}_{3}$ & 5.2 & 50 \\
$\mathrm{NaNO}_{3}$ & 8.0 & 547 \\
$\left(\mathrm{NH}_{2}\right)_{2} \mathrm{CO}$ & 8.8 & 300 \\
$\mathrm{None}$ & 8.1 & 118 \\
\hline
\end{tabular}

Table II. Effect of Carbon Sources on the Lipase Production

One percent of each carbon source was added to the basal medium in place of wheat starch. Cultural conditions were described in MATERIALS AND METHODS.

\begin{tabular}{lcc}
\hline \multicolumn{1}{c}{ Carbon sources } & $\begin{array}{c}\text { Final } \\
\mathrm{pH}\end{array}$ & $\begin{array}{c}\text { Lipase activity in } \\
\text { supernatant fluid } \\
(\mathrm{u} / \mathrm{ml})\end{array}$ \\
\hline Fructose & 8.4 & 950 \\
Glucose & 8.0 & 600 \\
Lactose & 8.2 & 670 \\
Glycerol & 8.6 & 10 \\
Na-Tartarate & 8.0 & 730 \\
Na-Acetate & 8.0 & 800 \\
Na-Citrate & 8.0 & 820 \\
Na-Citrate+Fructose & 8.4 & 1300 \\
Na-Acetate + Fructose & 8.4 & 1180 \\
Wheat starch & 8.1 & 630 \\
None & 7.9 & 660 \\
\hline
\end{tabular}


Table III. Effect of Nonionic Surfactants on the Lipase Production

To the basal culture medium, 0.5 percent of each surfactant was added. Cultural conditions were described in Materials AND Methods.

\begin{tabular}{|c|c|c|c|c|}
\hline Surfactants & $n^{c}$ & HLB & Final $\mathrm{pH}$ & $\begin{array}{l}\text { Lipase activity in } \\
\text { supernatant fluid }(\mathrm{u} / \mathrm{ml})\end{array}$ \\
\hline $\mathrm{S}^{a}$ monostearate & - & 5.1 & 8.5 & 143 \\
\hline $\mathrm{POE}^{b}$ oleyl ether & 5 & 8.8 & 7.4 & 95 \\
\hline POE stearyl ether & 6 & 9.4 & 7.7 & 306 \\
\hline POE lauryl ether & 6 & 10.5 & 7.5 & 105 \\
\hline POE $S$ trioleate & 20 & 11.0 & 8.0 & 244 \\
\hline POE lauryl ether & 8 & 12.1 & 7.6 & 95 \\
\hline POE oleyl ether & 13 & 13.6 & 8.1 & 422 \\
\hline POE lauryl ester & 12 & 13.7 & 8.3 & 220 \\
\hline POE stearyl ether & 13 & 13.9 & 8.4 & 550 \\
\hline POE cetyl ether & 13 & 14.2 & 7.9 & 450 \\
\hline POE S monooleate & 20 & 15.3 & 8.1 & 197 \\
\hline None & & & 8.2 & 155 \\
\hline
\end{tabular}

a Sorbitan.

b Polyoxyethylene $\mathrm{H}\left(\mathrm{OCH}_{2} \mathrm{CH}_{2}\right)_{n}{ }^{-}$.

c " $n$ " means the number of polymerization of oxyethylene.

acetate, $\mathrm{Na}$-citrate and fructose. The combination of fructose and citrate was the most favourable for the enzyme production. Glycerol was effective for bacterial growth but remarkably inhibited enzyme production. A favourable ratio of fructose and $\mathrm{NaNO}_{3}$ was found to be $1.25 \%$ of fructose and $0.75 \%$ of $\mathrm{NaNO}_{3}$.

(c) Effect of nonionic surfactants. To the basal medium $0.5 \%$ of nonionic surfactants was added and their effects on the enzyme production were investigated. Polyoxyethylene alkyl ethers whose HLB were in the range of $13.6 \sim 14.2$ were favourable for the enzyme production as shown in Table III. Polyoxyethylene stearyl ether was the most effective.

(d) Effect of minerals. As trace elements, $1 \mathrm{~mm}$ mineral salts were added to the basal medium and their effects on the enzyme production were investigated. As shown in Table IV, $\mathrm{FeSO}_{4}$ and $\mathrm{FeCl}_{3}$ were effective but $\mathrm{CoCl}_{2}$ inhibited the lipase production remarkably.

(e) Time course of lipase production. Time courses of the bacterial growth and enzyme production were investigated with a jar fermentor using the most favourable medium. The cultivation was carried out at $27^{\circ} \mathrm{C}$ with agitation of $400 \mathrm{rpm}$ and aeration of 0.75
Table IV. EFFect of Minerals on the Lipase Production

One $\mathrm{mm}$ each mineral salt was added to the basal culture medium. Cultural conditions were described in Materials AND Methods.

\begin{tabular}{lcc}
\hline Minerals & $\begin{array}{c}\text { Final } \\
\text { pH }\end{array}$ & $\begin{array}{c}\text { Lipase activity in } \\
\text { supernatant fluid }(\mathrm{u} / \mathrm{ml})\end{array}$ \\
\hline $\mathrm{MnCl}_{2}$ & 8.9 & 528 \\
$\mathrm{CuSO}_{4}$ & 8.3 & 577 \\
$\mathrm{CaCl}_{2}$ & 8.7 & 470 \\
$\mathrm{FeSO}_{4}$ & 8.7 & 700 \\
$\mathrm{MgSO}_{4}$ & 8.7 & 450 \\
$\mathrm{ZnCl}_{2}$ & 8.7 & 518 \\
$\mathrm{FeCl}_{3}$ & 8.7 & 680 \\
$\mathrm{SnCl}_{3}$ & 8.7 & 470 \\
$\mathrm{CoCl}_{3}$ & 8.3 & 96 \\
$\mathrm{None}$ & 8.7 & 472 \\
\hline
\end{tabular}

V.V.M. As shown in Fig. 1, the enzyme activity reached its peak after the maximum growth of bacteria and decreased moderately thereafter.

\section{Comparison of the enzyme with pancreatic lipase}

(a) Optimum $p H$ for enzyme activity. The activities of lipase-PL and lipase-Panc at various $\mathrm{pHs}$ were measured according to assay 


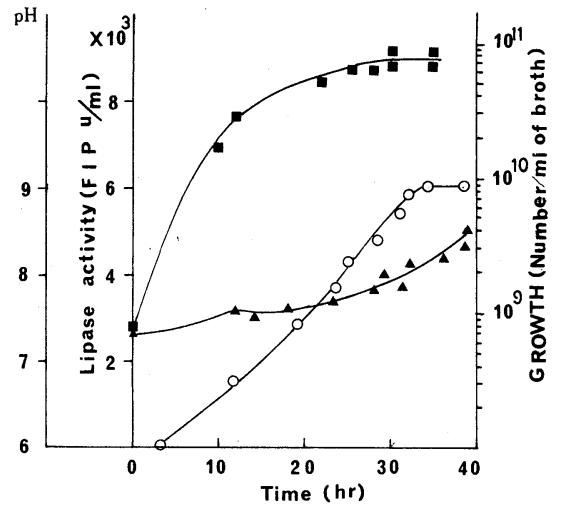

Fig. 1. Time Courses of Bacterial Growth and Enzyme Production.

The culture medium consisted of $3 \%$ kinako, $0.5 \%$ citrate, $1.25 \%$ fructose, $0.75 \% \quad \mathrm{NaNO}_{3}, 0.2 \% \quad \mathrm{~K}_{2} \mathrm{HPO}_{4}, 0.5 \%$ polyoxyethylene stearyl ether $(\mathrm{HLB}=13.9)$, and $0.028 \%$ $\mathrm{FeSO}_{4} \cdot 7 \mathrm{H}_{2} \mathrm{O}$. Cultural conditions were as follows: volume of the medium was 15 liters in a 30 -liter jar, temperature was $27^{\circ} \mathrm{C}$, aeration was 0.5 V.V.M., and agitation was $400 \mathrm{rpm}$. The lipase activity in the culture broth was determined according to assay method II.

$\mathrm{O}$, lipase activity; $\boldsymbol{\square}$, bacterial growth; $\boldsymbol{\Delta}, \mathrm{pH}$.

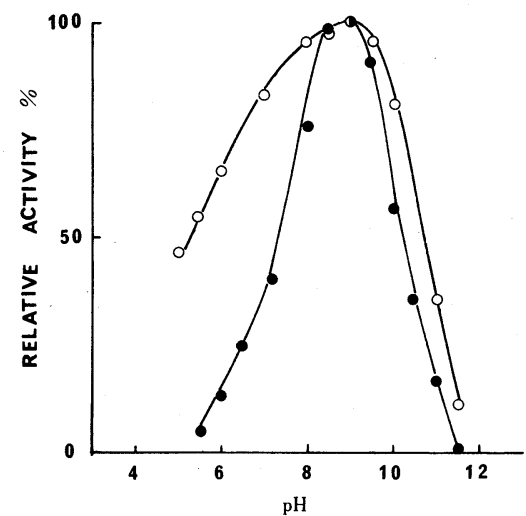

Fig. 2. Optimum $\mathrm{pH}$ for Lipase Activity.

The enzyme activities of lipase-PL $(O)$ and lipase-Panc (O) were determined according to assay method I. They were expressed as percentage relative to that at $\mathrm{pH} 9.0$, which was taken as $100 \%$. Buffer systems; pH $5.0 \sim 8.0$, McIlvaine buffer; $\mathrm{pH} 8.0 \sim 11.0$, Atkins and Pantin buffer; $\mathrm{pH} 11.0 \sim 12.0, \mathrm{Na}_{2} \mathrm{HPO}_{4}-\mathrm{NaOH}$ buffer.

method I, except that $0.5 \mathrm{ml}$ of $8 \%$ STC solution was used in place of distilled water. As shown in Fig. 2, both lipases have optimum pHs for activity around 9.0, however, lipase$\mathrm{PL}$ was active in a wider $\mathrm{pH}$ range than lipase-

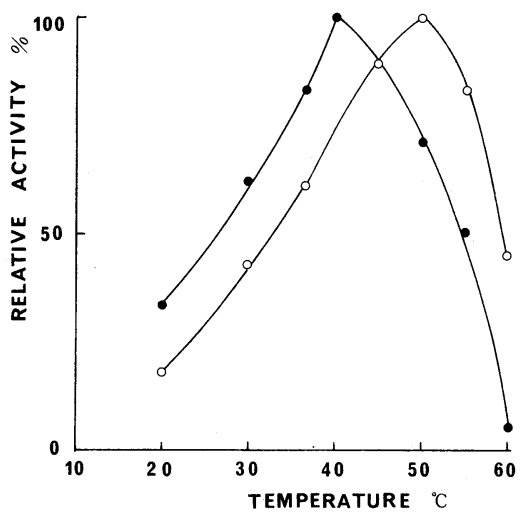

Fig. 3. Optimum Temperature for Lipase Activity.

The enzyme activity at each temperature was determined according to assay method II. The activity was expressed as percentage relative to that at $50^{\circ} \mathrm{C}$ with lipase-PL (O) and at $40^{\circ} \mathrm{C}$ with lipase-Panc (O), which were taken as $100 \%$, respectively.

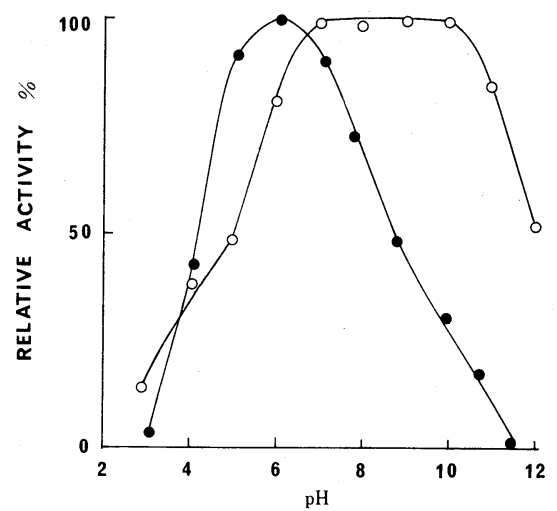

FIG. 4. Effect of $\mathrm{pH}$ on Lipase Stability.

After treatment of lipase preparations in each buffer for $24 \mathrm{hr}$ at $8^{\circ} \mathrm{C}$, the residual activity was measured according to assay method II. The activity remaining was expressed as percentage relative to that at $\mathrm{pH} 9.0$ (lipase-PL, $\mathrm{O}$ ) and at pH 6.0 (lipase-Panc, $)$ ), respectively, which were taken as $100 \%$. Buffer systems; $\mathrm{pH} 2.7 \sim 8.0$, McIlvaine buffer; $\mathrm{pH} 8.5 \sim 12.0$, glycine buffer.

Panc.

(b) Optimum temperature for lipase activity. Optimum temperatures for the lipase activities are shown in Fig. 3; they were $50^{\circ} \mathrm{C}$ for lipasePL and $40^{\circ}$ for lipase-Panc.

(c) Effect of $p H$ on lipase stability. The stability of the lipase solutions of various $\mathrm{pHs}$ is shown in Fig. 4. While lipase-Panc was 


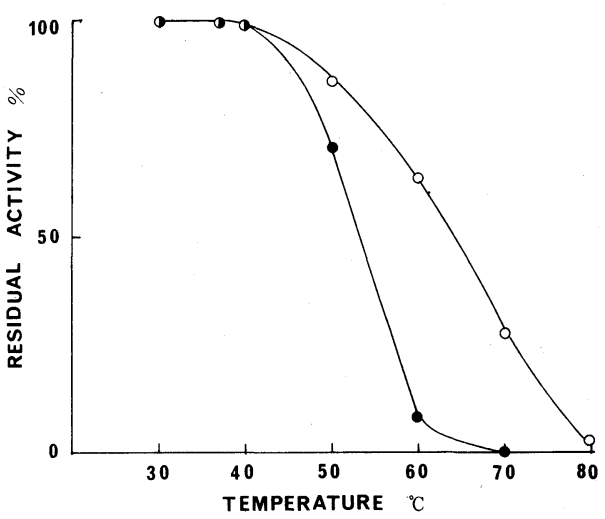

FIG. 5. Effect of Temperature on Lipase Stability.

An aliquot of $1 \%$ lipase solution was incubated at various temperatures for $10 \mathrm{~min}$ at $\mathrm{pH} 9.0$ (lipase-PL, O) and at pH 6.0 (lipase-Panc, O). The enzyme activity remaining was determined according to assay method II and expressed as percentage relative to that at $30^{\circ} \mathrm{C}$, which was taken as $100 \%$.
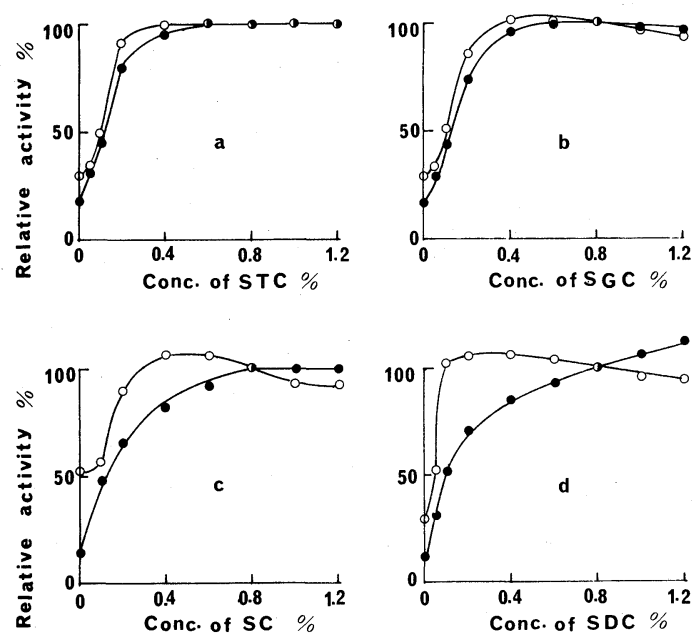

Fig. 6. Effect of Bile Salts on the Lipase Activity.

The lipase activity was measured according to assay method II in the presence of various concentrations of bile salts in the reaction mixture and expressed as percentage relative to that of $0.8 \%$ of each bile salt, which was taken as $100 \%$.

$\bigcirc$, lipase-PL;, lipase-Panc.

stable between $\mathrm{pH} 5$ and 7, lipase-PL was stable in a wider range of $\mathrm{pH}$ from 6 to 11 .

(d) Effect of temperature on lipase stability. Thermal stability of both lipases was investigated at the most stable $\mathrm{pH}$ for each lipase: $\mathrm{pH}$

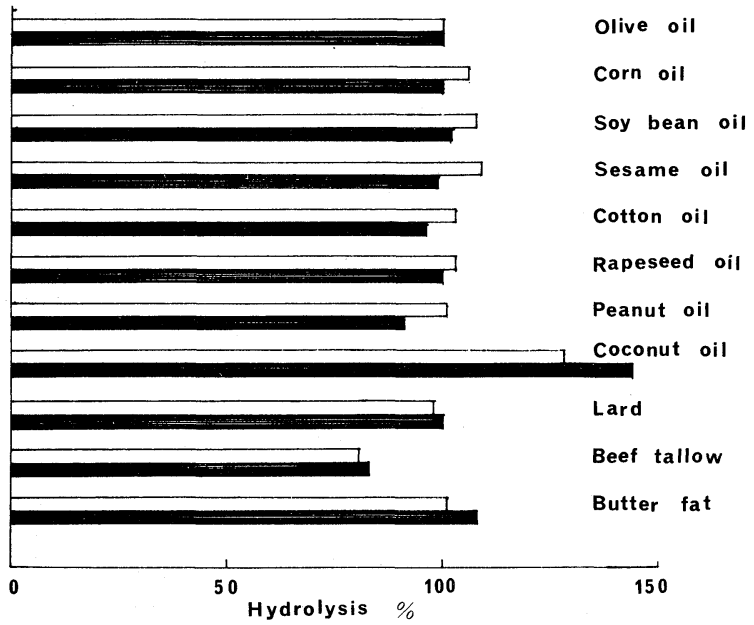

FIG. 7. Hydrolysis of Natural Fats and Oils.

Experimental conditions were described in MATERIALS AND METHODS. Degree of hydrolysis was expressed as percentage relative to that in the case of olive oil, which was taken as $100 \%$.

$\square$, lipase-PL; $\square$, lipase-Panc.

\section{TABle V. Hydrolysis OF SYNTHETIC ESTERS}

According to assay method II, each synthetic ester was hydrolysed. The nezyme activity for the esters was expressed as percentage relative to that for olive oil, which was taken as $100 \%$.

\begin{tabular}{lcc}
\hline \multicolumn{1}{c}{ Esters } & $\begin{array}{c}\text { Lipase-PL } \\
(\%)\end{array}$ & $\begin{array}{c}\text { Lipase-Panc } \\
(\%)\end{array}$ \\
\hline Methyl butyrate & 11 & 13 \\
Methyl caproate & 8 & 4 \\
Methyl caprylate & 22 & 7 \\
Tween 80 & 7 & 1 \\
Tween 85 & 27 & 1 \\
Span 80 & 30 & 8 \\
Tributyrin & 180 & 500 \\
Tri- $n$-caproin & 66 & 44 \\
Tri- $n$-caprin & 136 & 133 \\
Triolein & 183 & 167 \\
\hline
\end{tabular}

9.0 for lipase-PL and $\mathrm{pH} 6.0$ for lipase-Panc, and the results are shown in Fig. 5. Lipase-PL was more stable than lipase-Panc towards heat treatment above $40^{\circ} \mathrm{C}$.

(e) Effect of bile salts. Effects of sodium salts of four bile acids on lipase activities were investigated using assay method II. The results are shown in Fig. 6a, b, c and d. The activities of both lipases were stimulated remarkably in 


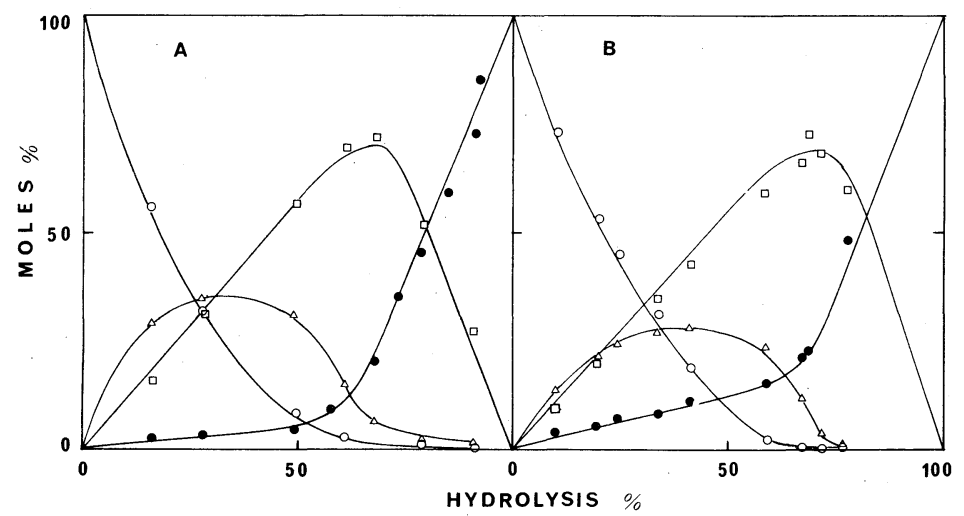

FIG. 8. Hydrolysis of Olive Oil by Lipase-Panc (A) and Lipase-PL (B).

Experimental conditions and method of analysis of hydrolyzate were described in MATERIALS AND METHODS. $\bigcirc$, triglyceride; $\triangle$, diglyceride; $\square$, monoglyceride; $\bigcirc$, glycerine.

the presence of the bile salts. The activity of lipase-PL was much more stimulated than that of lipase-Panc with a lower concentration of bile salts. Particularly, the stimulation was remarkable in the case of sodium cholate and sodium deoxycholate.

(f) Hydrolysis of natural fat or oil. The hydrolysis of natural fats and oils by both lipases is shown in Fig. 7: Both lipases hydrolysed the fats or oils tested to the same degree as olive oil. Among them, coconut oil was hydrolysed most rapidly.

(g) Hydrolysis of synthetic esters. The hydrolysis of various esters of fatty acid by both lipases are shown in Table V. Both lipases were more active on triglycerides than on sorbitan esters and methyl esters of fatty acids. LipasePL, however, was more active on sorbitan esters of fatty acids than lipase-Panc.

(h) Hydrolysis of olive oil. Both lipases similarly hydrolysed olive oil and the rate of hydrolysis reached above $90 \%$. Hydrolysis products of olive oil with the lipases were analyzed by TLC in order to compare the amounts of mono- and diglycerides accumulated. The results are shown in Fig. 8. When the hydrolysis rate of olive oil with both lipases reached about $70 \%$, triglyceride was not detected and the maximal accumulation of monoglyceride was observed. The results coincided with each other in both cases.
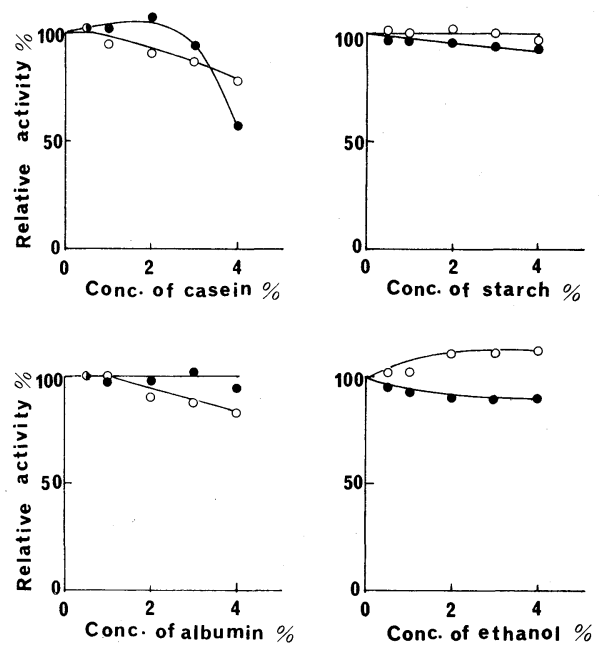

FIG. 9. Effect of Components of Food on the Lipase Activity.

The lipase activity was determined according to assay method II in the presence of various concentrations of components of food in the reaction mixture and expressed as percentage relative to those in the absence of the components of food, which were taken as $100 \%$.

O, lipase-PL;, , lipase-Panc.

(i) Effect of components of food on lipase activity. Each component of food such as milk casein, egg albumin, starch or ethanol was added to the assay mixture and the lipase activities were determined. As shown in Fig. 9, the activity of lipase-PL was stimulated by ethanol and was not affected by starch but it 
was suppressed slightly by milk casein and egg albumin. On the other hand, the activity of lipase-Panc was slightly suppressed by the components of food except egg albumin.

\section{DISCUSSION}

The main objective of this research was to obtain a large amount of such lipases as pancreatin via fermentation with a microorganism. In the previous report, the authors pointed out three important properties of pancreatic lipase as a digestive aid. The first of these properties is that the lipase is active on the alkaline side. Several researchers have lately found lipases whose optimum $\mathrm{pHs}$ were in the alkaline region. For instance, lipases from Candida paralipolytica, ${ }^{9)}$ Mucor lipolyticum, ${ }^{10)}$ Sclerotinia libertiana ${ }^{11)}$ Humicola lanuginosa ${ }^{3)}$ Pseudomonas nitroreducens var. thermotolerans ${ }^{1)}$ and Achromobactor sp. ${ }^{12)}$ were reported to belong to this type. As far as the optimum $\mathrm{pH}$ of the enzyme is concerned, a number of microbial lipases similar to pancreatic lipase have already been found. However, the $\mathrm{pH}$ activity curve of lipase-PL is more similar to that of pancreatic lipase than those mentioned above.

The second desirable property is that the enzyme activity should be stimulated by bile salts. A group of microorganisms which produces lipases stimulated by bile salts includes Phycomyces sp., ${ }^{5)}$ Mucor japanicus, ${ }^{4)}$ Sclerotinia libertiana ${ }^{11)}$ and Candida paralipolytica. ${ }^{13)}$ However, the optimum $\mathrm{pH}$ for the enzyme activity of the lipases from Mucor, Pseudomonas and Pycomyces were reported to be neutral or slightly acidic, therefore, they are thought to be different from pancreatic lipase. The lipase of Sclerotinia libertiana was reported to be an alkaline enzyme and stimulated by bile salts. It was stimulated 2.4 times at $\mathrm{pH} 6.0$ but only 1.3 times at $\mathrm{pH} 8.5$ in the presence of $0.4 \%$ STC. Furthermore, the enzyme activity of Candida paralipolytica was observed only in the presence of anionic surfactants such as STC and sodium lauryl sulfate. ${ }^{13,14)}$ Lipase-PL was stimulated by bile salts as shown in Fig. 6 and the stimulation curves against the concentration of STC and SGC were very similar to those of pancreatic lipase, and the optimum $\mathrm{pH}$ of this enzyme also agreed with that of pancreatic lipase.

The third property is the accumulation of monoglyceride during enzymatic hydrolysis of fats and oils. Frazer ${ }^{15)}$ demonstrated that hydrolysis of olive oil by pancreatic lipase brought about a monoglyceride intermediate which he thought played an important role in rapid digestion and absorption of fats and oils by emulsifying oils and fatty acids together with bile salts. Constantin ${ }^{16)}$ reported that during the course of hydrolysis of olive oil by pancreatic lipase, $80 \mathrm{~mol}^{\circ} \%$ of monoglyceride and $40 \mathrm{~mol} \%$ of diglyceride were accumulated. With respect to microbial lipase, the lipase from Aspergillus niger ${ }^{17}$ accumulated 24 $\mathrm{mol} \%$ of monoglyceride and the enzyme of Rhizopus delemar ${ }^{17)}$ accumulated $55 \mathrm{~mol} \%$ during hydrolysis of triolein. The lipase from Pycomyces sp. and Candida cylindracea ${ }^{18)}$ accumulated only 8 and $5 \mathrm{~mol} \%$ of monoglyceride, respectively. As mentioned above, the accumulation of monoglyceride during hydrolysis of fats and oils by microbial lipases was less than that by pancreatic lipase. In contrast to these observations, lipase-PL accumulated 70 and $28 \mathrm{~mol}^{\%}$ of mono- and diglyceride, respectively, and this seemed to agree well with the case of pancreatic lipase. In addition, both lipases similarly hydrolyzed natural fats and oils as well as olive oil.

There were, however, some differences between the two lipases in thermal stability, $\mathrm{pH}$ stability and optimum temperature. Lipase-PL was always more stable than pancreatic lipase.

Acknowledgment. The authors wish to thank Dr. Akira Shinoda, the President of Meito Sangyo Co., Ltd., for his encouragement throughout this work.

\section{REFERENCES}

1) N. Watanabe, Y. Ota, Y. Minoda and K. Yamada, Agric. Biol. Chem., 41, 1356 (1977).

2) Y. Kosugi and H. Suzuki, J. Ferm. Technol., 51, 895 (1973). 
3) Wen-Hsiung Liu, T. Beppu and K. Arima, Agric. Biol. Chem., 36, 1923 (1972).

4) M. Sugiura and T. Ogiso, Eisei Kagaku, 13, 257 (1967).

5) K. Tomoda, S. Nakamura and K. Maeshima, Abstracts of Papers, Annual Meeting of the Agricultural Chemical Society of Japan, 1976, p. 333.

6) Y. Kokusho, H. Machida and S. Iwasaki, Agric. Biol. Chem., 46, 1159 (1982).

7) J. Choay et al., J. Mond. Pharm., 3, 11 (1968).

8) D. J. Hanahan and J. N. Olley, J. Biol., 231, 814 (1958).

9) Y. Ota, T. Nakamiya and K. Yamada, Agric. Biol. Chem., 34, 1372 (1970).

10) K. Nagaoka and Y. Yamada, Agric. Biol. Chem., 37, 2739 (1973).
11) H. Kataoka, Yakuzaigaku, 28, 177 (1968).

12) Y. Kokusho, H. Machida and A. Shinoda, Abstracts of Papers, Annual Meeting of the Agricultural Chemical Society of Japan, 1973, p. 315.

13) Y. Ota and K. Yamada, Agric. Biol. Chem., 30, 353 (1966).

14) Y. Ota, Hakkokagaku Kaishi, 22, 419 (1964).

15) A. C. Frazer and H. G. Sammonos, Biochem. J., 39, 122 (1945).

16) M. J. Constantin, D. Pasero and P. Desnuelle, Biochim. Biophys. Acta, 43, 103 (1960).

17) M. Iwai, K. Tsujisaka and J. Fukumoto, Hakkokagaku Kaishi, 22, 419 (1964).

18) T. Higashi and H. Machida, Kobunshi, 16, 1224 (1967). 